\title{
Increased expression of integrin-linked kinase is associated with shorter survival in non-small cell lung cancer Iwao Takanami*
}

\author{
Address: First Department of Surgery, Teikyo University School of Medicine, Tokyo, Japan \\ Email: Iwao Takanami* - takanami@med.teikyo-u.ac.jp \\ * Corresponding author
}

Published: 05 January 2005

BMC Cancer 2005, 5:I doi:10.1/86/147|-2407-5-I

This article is available from: http://www.biomedcentral.com/I47/-2407/5/I

(C) 2005 Takanami; licensee BioMed Central Ltd.

This is an Open Access article distributed under the terms of the Creative Commons Attribution License (http://creativecommons.org/licenses/by/2.0), which permits unrestricted use, distribution, and reproduction in any medium, provided the original work is properly cited.
Received: 12 August 2004

Accepted: 05 January 2005

\begin{abstract}
Background: Integrin-linked kinase (ILK) promotes tumor growth and invasion. Increased ILK expression is correlated with progression of several tumor types, but the expression of ILK has not been investigated in patients with non-small cell lung cancers (NSCLCs).
\end{abstract}

Methods: We investigated ILK expression in patients with NSCLC by means of immunohistochemistry.

Results: ILK expression was significantly associated with tumor grade, $T$ status, lymph node metastasis and stage. $(p=0.0169$ for tumor grade; $p=0.0006$ for $T$ status; $p=0.0002$ for lymph node metastasis; $p<0.000$ I for stage). The 5 -year survival rates for patients with strong and weak or no ILK expression levels were $20 \%$ and $59 \%$, respectively: the difference was statistically significant $(\mathrm{p}<0.000 \mathrm{I})$. A multivariate analysis of survival revealed that ILK expression, T status, $N$ status and vascular invasion were statistically significant prognostic factors $(P=0.0218$ for ILK; $p=$ 0.0046 for T status; $\mathrm{p}<0.000$ I for $\mathrm{N}$ status; $\mathrm{p}<0.000$ I for vascular invasion).

Conclusions: Our study demonstrates that increased expression of ILK is a poor prognostic factor in patients with NSCLC.

\section{Background}

Interaction of cells with the extracellular matrix regulates many physiological and pathological processes. These interactions are mediated by a large family of cell surface receptors known as integrins, which recognize several extracellular matrix proteins, including fibronectin, collagens, and vitronectin [1]. Integrins act as the bridge between extracellular matrix components and the cytoskeleton and other proteins, regulating cell survival, proliferation, differentiation, and migration [1]. Integrins are important mediators of tumor invasion and metastasis through interaction with extracellular matrix. All integrins are heterodimers composed of one copy each of two sub- units, $\alpha$ and $\beta$. Many studies examined the association between integrins and clinicalpathology or prognosis in lung cancer. Reduced integrin $\alpha 3 \beta 1$ expression was reported to be a factor of poor prognosis in pulmonary adenocarcinoma [2]. Increased expression of integrin $\beta 1$ was reported to be a poor prognosis in small cell lung cancer [3]. Integrin $\alpha 5 \beta 1$ was reported to be associated with lymph node metastasis of non-small cell lung cancer (NSCLC) [4], or to be a prognostic factor in node-negative NSCLC [5].

Integrin-linked kinase (ILK) interacts with cytoplasmic domain of both $\beta 1$ and $\beta 3$ integrins and is activated by 
cell- extracellular matrix interactions [6]. Overexpression of ILK in epithelial cells results in anchorage-independent cell growth with increased cell cycle progression [7]. Furthermore, increased ILK expression is correlated with progression of several tumor types, including prostate [8], gastric [9], and colon carcinomas [10]. However, to our knowledge, the expression of ILK has not been investigated in patients with NSCLC. Thus, we investigated ILK expression in series of 134 cases of curatively resected NSCLC by means of immunohistochemical assays to evaluate its clinical significance.

\section{Methods \\ Patients}

A total of 134 patients ( 88 men and 46 women; mean age, 65 years; age range, 28 to 80 years) with NSCLC were studied (consecutive cases). All patients in this study had undergone curative tumor resection in our department between 1995 and 1998. Patients who died within 30 days after surgery and those who underwent exploratory thoracotomy were excluded from the study. Patients with a past history of another type of cancer were also excluded. With regard to histological type, 75 were adenocarcinomas, 54 were squamous cell carcinomas and 5 were large cell lung carcinomas. The lesions of these 134 patients were staged on both operative and pathologic findings according to the UICC TNM classification [11] (1997). There were 36 patients $(27 \%)$ with stage Ia, 37 (28\%) with stage Ib, 3 (2\%) with stage IIa, 18 (13\%) with stage IIb, and $40(30 \%)$ with stage IIIa. None of the study subjects received pre- or postoperative chemotherapy and median follow-up of the patients was 75.3 months (range 60-96 months) and their outcomes were known.

\section{Immunohistochemical staining}

Resected tissue specimens were fixed in formalin, embedded in paraffin, and cut into $3-\mu \mathrm{m}$ serial sections. The sections were subjected to hematoxylin-eosin staining and immunohistochemical analysis with ILK. A mouse antiILK monoclonal antibody (Santa Cruz Biotechnology, CA, USA) was used, and immunohistochemical staining was based on the avidin-biotin-peroxidase complex method and was performed with a Vestastatin kit (Vector, Burlingame, CA). Negative control sections were treated using nonspecific IgG in the primary antibody.

\section{Determination of expression of ILK}

Immunoreactivity was graded as from - to +++, according to the number of cells stained. Grades was defined as follow as: -, no positive cells; \pm , less than $5 \%$ of tumor cells showed immunoreactivity;,$+ 5-50 \%$ of tumor cells showed immunoreactivity;,$++ 50-80 \%$ of tumor cells showed immunoreactivity; +++ , over $80 \%$ of tumor cells showed immunoreactivity. Grades ++ and +++ were regarded as strong expression, and grades \pm and + were regarded as weak expression. The results of immunohistochemical staining were evaluated independently by three observers with no prior knowledge of patients' clinical data. The evaluation was suitable for $96 \%$ of the samples. The other specimens (4\%) were re-evaluated independently, then classified according to the classification given most frequently by the observers. In this study, we compared the group of tumors of strong ILK expression with the group of tumors of weak or no ILK expression.

\section{Statistical analysis}

The association between ILK expression and clinical data was statistically evaluated by using Mann-Whitney U test or the chi-square test. Survival curves were calculated by the Kaplan-Meier method and were compared using the log-rank test. The correlation of variables with survival was analyzed by multivariate analysis using a Cox proportional hazards model. All statistical analyses were performed using the StatView software package (Abaracus Concepts, Berkeley CA). A P value of $<0.05$ was considered statistically significant.

\section{Results}

\section{Expression of ILK and clinicopathologic parameters}

In non-neoplastic lung tissue, ILK was not detected in epithelial cells, while ILK expression was found in stromal cells including fibroblasts and infiltrating lymphocytes (Figure 1). In the cancer cells of many patients, ILK expression was detected in both cytoplasm and nuclei (Figure 2, and 3$)$. Of the 134 patients, $6(4 \%)$ were classified as,- 34 $(25 \%)$ as, $\pm 53(40 \%)$ as,$+ 25(19 \%)$ as ++ , and $16(12 \%)$ as +++. Patients with ILK ++ and +++ were placed together in a strong ILK group and were compared with weak or no ILK group. Tumor cells expressed ILK protein in most NSCLC cases, and strong expression was detected 31\% (41 of 134) of the cases. Stromal cells in cancer lesion were also positive to ILK, and rate of positive cells and intensity of the staining were not different from those of stromal cells in non-neoplastic lesion. As shown in Table 1 , there were no significant differences between ILK expression status and clinical factors of age, gender, histology, lymphatic invasion and vascular invasion. However, the expression of ILK protein was significantly associated with tumor grade, T status, lymph node metastasis and stage $(\mathrm{p}=0.0169$ for tumor grade; $\mathrm{p}=0.0006$ for $\mathrm{T}$ status; $\mathrm{p}=0.0002$ for lymph node metastasis; $\mathrm{p}<0.0001$ for stage).

\section{Relationship between ILK expression and overall survival}

The 5-year survival rates for the groups with strong, and weak or no for ILK expression in their tumors were 20\% and $59 \%$ respectively: the difference was statistically significant $(\mathrm{p}<0.0001)$ (Figure 4$)$. The univariate survival analysis revealed that tumor grade, $\mathrm{T}$ status, $\mathrm{N}$ status, stage, lymphatic invasion, vascular invasion and ILK 
Table I: Clinicopathologic characteristics of patients with NSCLC classified according to ILK

\begin{tabular}{|c|c|c|c|}
\hline \multirow[t]{2}{*}{ Characteristic } & \multicolumn{2}{|c|}{ Expression of ILK } & \multirow[t]{2}{*}{ P-value } \\
\hline & weak or none $(n=93)$ & strong $(n=4 I)$ & \\
\hline \multicolumn{4}{|l|}{ Age } \\
\hline $\mathrm{MEAN} \pm \mathrm{SD}$ & $64.6 \pm 11.0$ & $64.5 \pm 9.3$ & 0.3412 \\
\hline \multicolumn{4}{|l|}{ Gender } \\
\hline Male & 57 & 31 & \\
\hline Female & 36 & 10 & 0.1077 \\
\hline \multicolumn{4}{|l|}{ Histology } \\
\hline Adenocarcinoma & 54 & 21 & \\
\hline Squamous cell ca. & 37 & 17 & \\
\hline Large cell ca. & 2 & 3 & 0.4771 \\
\hline \multicolumn{4}{|l|}{ Tumor grade } \\
\hline Well differentiated & 38 & 9 & \\
\hline Mode differentiated & 37 & 15 & \\
\hline Poorly differentiated & 18 & 17 & 0.0169 \\
\hline \multicolumn{4}{|l|}{$\mathrm{T}$ status } \\
\hline TI & 34 & 6 & \\
\hline $\mathrm{T} 2$ & 49 & 20 & \\
\hline T3 & 10 & 15 & 0.0006 \\
\hline \multicolumn{4}{|l|}{ Nodal status } \\
\hline No & 69 & 18 & \\
\hline NI & 7 & 1 & \\
\hline N2 & 17 & 22 & 0.0002 \\
\hline \multicolumn{4}{|l|}{ Stage } \\
\hline $\mathrm{la} / \mathrm{lb}$ & 62 & 11 & \\
\hline Ila/llb & 14 & 7 & \\
\hline IIla & 17 & 23 & $<0.0001$ \\
\hline \multicolumn{4}{|l|}{ Lymphatic invasion } \\
\hline Negative & 42 & 15 & \\
\hline Positive & 51 & 26 & 0.3548 \\
\hline \multicolumn{4}{|l|}{ Vascular invasion } \\
\hline Negative & 56 & 19 & \\
\hline Positive & 37 & 22 & 0.1360 \\
\hline
\end{tabular}

expression all were statistically significant prognostic factors ( $\mathrm{p}=0.0003$ for tumor grade; $\mathrm{p}<0.0001$ for T status; $\mathrm{p}<0.0001$ for N status; $\mathrm{p}<0.0001$ for stage; $\mathrm{p}<0.0001$ for lymphatic invasion; $\mathrm{p}<0.0001$ for vascular invasion; $\mathrm{p}<0.0001$ for ILk expression) (Table 2). However, age, gender, and histology were not significant factors. The multivariate survival analysis revealed that $\mathrm{T}$ status, $\mathrm{N}$ status, vascular invasion and ILK expression were statistically significant prognostic factors ( $\mathrm{p}=0.0046$ for T status; $\mathrm{p}<$ 0.0001 for $\mathrm{N}$ status; $\mathrm{p}<0.0001$ for vascular invasion; $\mathrm{p}=$ 0.0218 for ILK expression) (Table 3 ).

\section{Discussion}

Recent studies have indicated that ILK facilitated the phosphorylation of AKT, which is required for AKT activation [12]. Activation of AKT upregulates vascular endothelial growth factor expression, and AKT is known to induce angiogenesis and suppress apoptosis [12]. By regulating, the activity of AKT as well as glycogen synthase kinase 3, ILK facilitates the assembly and activity of the $\beta$-catenin/ LEF-1 transcription complex, and suppresses expression of the invasion suppressor E-cadherin $[13,14]$. Overexpression of ILK in epithelial cells results in anchorage- 


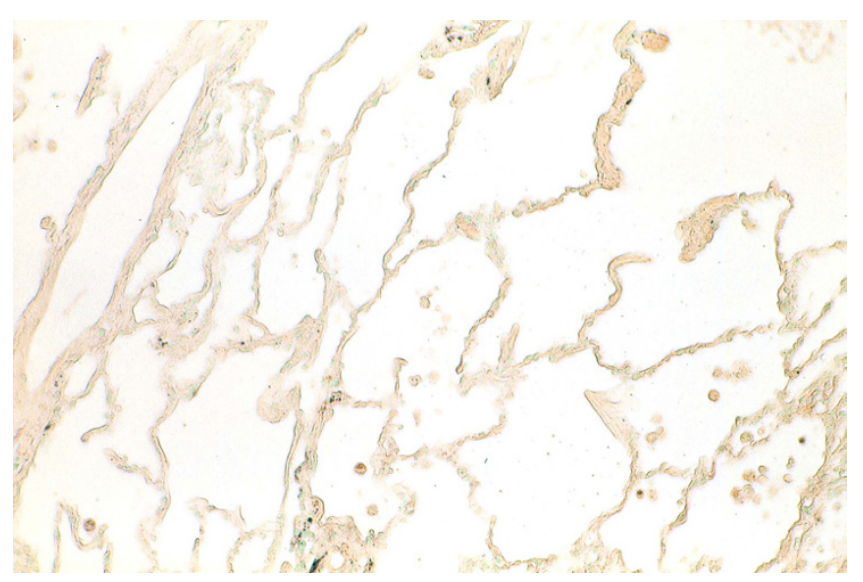

Figure I

Immunohistochemical studies of ILK in non-neoplastic pulmonary tissue and in NSCLC tissue. a non-neoplastic pulmonary tissue: ILK was not detected in epithelial cells, while ILK expression was found in many stromal cells.

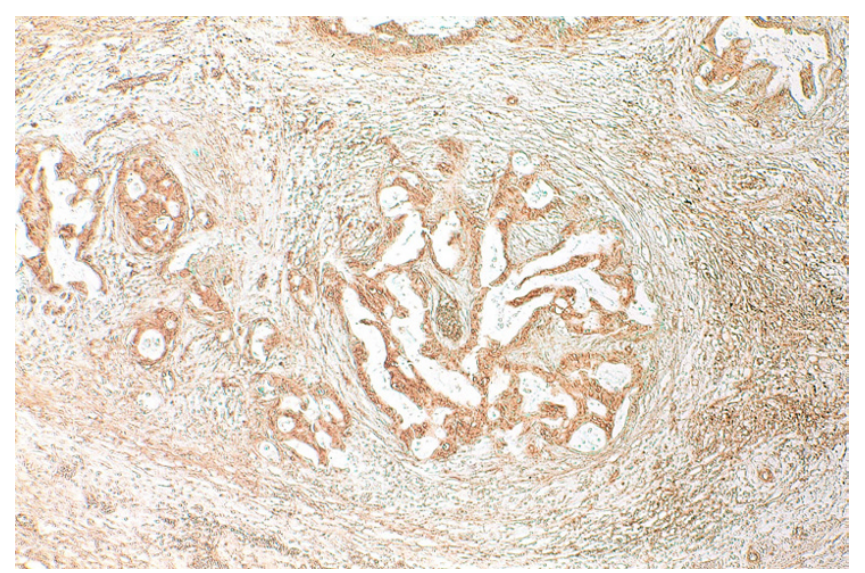

Figure 2

well differentiated adenocarcinoma: ILK protein was localized in both cytoplasms and nuclei. (Magnification, $\times 40$ (Figure I), $\times 16$ (Figure 2), and $\times 40$ (Figure 3$)$ ).

independent cell growth with increased cell cycle progression, and constitutive up-regulation of cyclin $\mathrm{D}$ and cyclin A expression [7]. Inhibition of ILK elicits cell cycle arrest and induces apoptosis [15]. Overexpression of ILK in epithelial cells induces tumorigenicity in nude mice, indicating that ILK can act as a proto-oncogene [16]. ILK is associated with a highly invasive phenotype of certain tumors [7].

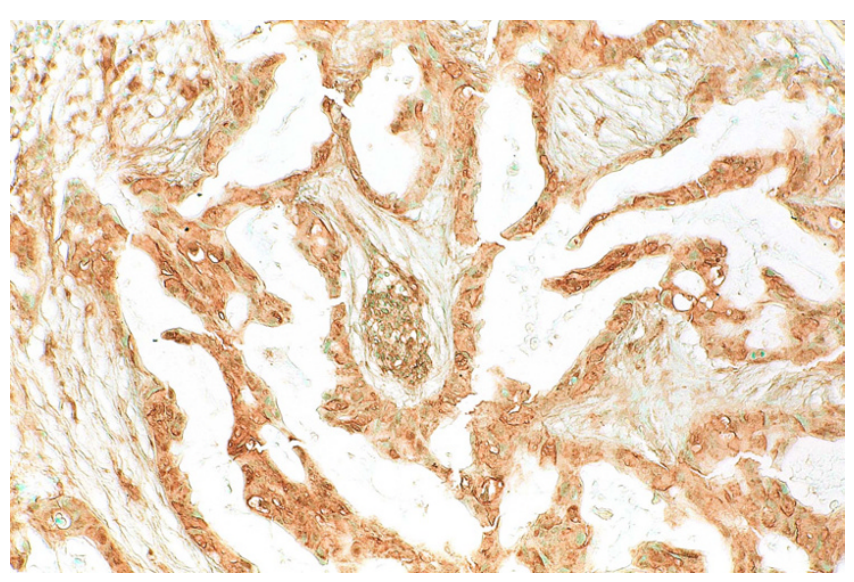

Figure 3

well differentiated adenocarcinoma: ILK protein was localized in both cytoplasms and nuclei. (Magnification, $\times 40$ (Figure I), $\times 16$ (Figure 2), and $\times 40$ (Figure 3)).

In the current study, we detected ILK expression using immunohistochemistry on tumors from patients with NSCLC. ILK was strongly expressed in $31 \%$ of tumor samples, whereas there was no ILK expression in noncancerous pulmonary tissue samples from the same patients, except for fibroblasts and infiltrating lymphocytes. These finding suggest that ILK expression may serve as a useful marker of NSCLC. ILK is very low in healthy cells. In cancer cells, however, ILK activity is often increased, possibly as a result of a malfunctioning of upstream components in the integrin and growth factor signaling pathways. We found a significant correlation between strong expression and advanced $\mathrm{T}$ status, $\mathrm{N}$ status and stage. No correlation was found age, gender or histology. These results suggest that ILK expression is correlated with tumor progression in NSCLC. Cases with strong ILK expression were reported to be significantly more frequent in advanced gastric carcinoma [9] and advanced melanoma [17]. ILK-mediated pathway that may enhance tumor progression is its regulation on MMP expression [18]. During tumor progression, MMPs facilitate the pathological processes of tumor invasion, angiogenesis, and metastasis by breaking down the extracellular matrix. The overexpression of ILK has been shown to be result of increased MMP-9 expression [18]. We also demonstrated that the expression of ILK correlated with tumor grade. Recent studies have also linked ILK expression to tumor grade of prostate [7], gastric [9] or ovarian carcinomas [19]. The overall prognosis of patients with strong ILK expression was significantly poorer than that of patients with weak or no expression. For stage I or stage II/IIIa patients, prognosis was poorer for those with strong ILK expression than for those with weak or no ILK expression, although the differences were 


\section{Survival rate}

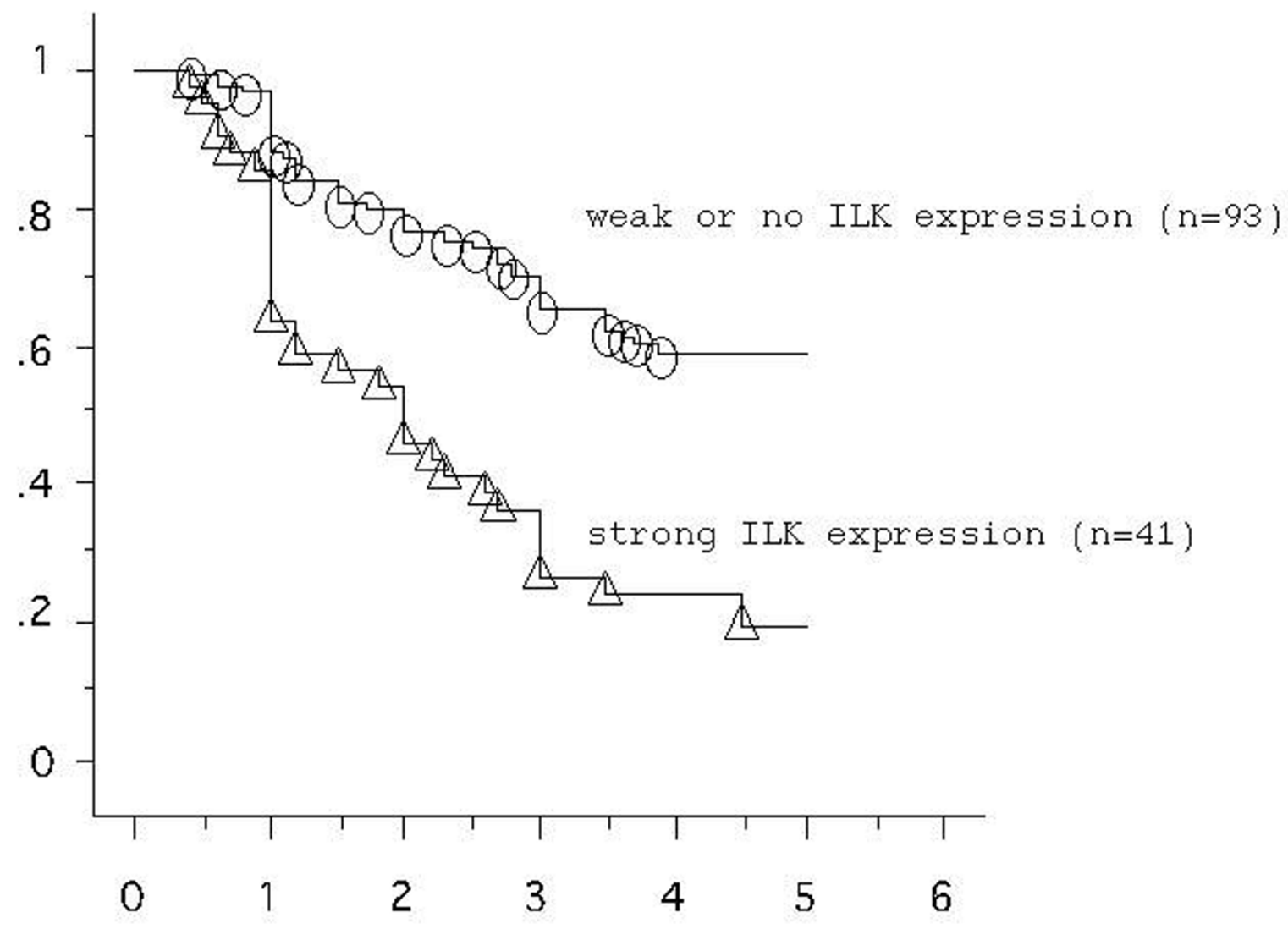

\section{Years after surgery}

\section{Figure 4}

Overall survival curves for patients classified according to expression of ILK. Five-year survival rates were $20 \%$ and $59 \%$ for patients in the strong ILK and weak or no ILK groups, respectively. A log-rank test revealed a significant difference between the two groups $(p<0.001)$.

Table 2: Univariate Analysis of Variables that Affected the Overall Survival Rate Determined by Cox Proportional Hazards Model

\begin{tabular}{|c|c|c|c|}
\hline Variable & Relative risk & $95 \% \mathrm{Cl}$ & $\mathrm{P}$-value \\
\hline Age $(<65$ yrs $/ \leqq 65$ yrs $)$ & 1.070 & $0.699-1.710$ & 0.080 \\
\hline Gender (male/female) & 1.537 & $0.866-2.383$ & 0.1605 \\
\hline Histology (SCC/others) & 1.174 & $0.688-2.005$ & 0.5560 \\
\hline Tumor grade (mode., poor/well) & 1.802 & $1.130-2.478$ & 0.0003 \\
\hline $\mathrm{T}$ status $(\mathrm{T} 2, \mathrm{~T} 3 / \mathrm{TI})$ & 2.669 & $1.878-3.794$ & $<0.0001$ \\
\hline $\mathrm{N}$ status (NI, N2/N0) & 5.911 & $3.600-9.705$ & $<0.0001$ \\
\hline Stage (stage II, III/Stage I) & 8.143 & $4.851-12.255$ & $<0.0001$ \\
\hline Lymphatic invasion (positie/negative) & 3.634 & $2.074-6.367$ & $<0.0001$ \\
\hline Vascular invasion (positive/negative) & 3.198 & $\mid .974-5.181$ & $<0.0001$ \\
\hline ILK (strong/weak or no) & 2.926 & $1.827-4.686$ & $<0.0001$ \\
\hline
\end{tabular}


Table 3: Risk Factors that Affected the Overall Survival Rate Determined by the Cox Proportional Hazards model

\begin{tabular}{lccc}
\hline Variable & Relative risk & $95 \% \mathrm{Cl}$ & P-value \\
\hline Tumor grade (mod., poor/wel) & 1.238 & $0.858-1.786$ & 0.2543 \\
T status (T2, T3/TI) & 1.845 & $1.208-2.818$ & 0.0046 \\
N status (NI, N2/N0) & 3.897 & $2.241-6.775$ & $<0.0001$ \\
Vascular invasion (positive/negative) & 2,981 & $1.733-5.127$ & $<0.0001$ \\
ILK (strong/weak or no) & 1.844 & $1.093-3.112$ & 0.0218 \\
\hline
\end{tabular}

not significant (data not shown). Strong expression of ILK protein was reported to be significantly associated with presence of nodal metastasis $[9,17]$. The univariate survival analysis revealed ILK expression was a significant prognostic factor as well as $\mathrm{T}$ status, $\mathrm{N}$ status, stage, lymphatic invasion and vascular invasion. The status of ILK expression might be dependent on the status of lymph node metastasis or other variables. So the multivariate analysis for survival was performed. In the current study, the multivariate analysis revealed that ILK expression was picked up for its independent level of prognostic significance. Our results also showed that the tumors with a strong expression of ILK were associated with an increased recurrence, which suggests that patients with strong ILK expression may be prone to metastasis, or may already have occult systemic diseases. ILK expression level plays one of the key roles in the biology of NSCLC and defines a more aggressive tumor phenotype of NSCLC. Preoperative adjuvant therapy in NSCLC is designed to improve survival and reduce local recurrence. Recent reports have shown that preoperative adjuvant therapy has led to an increase in overall survival of NSCLC patients [20,21]. It is possible that this preoperative adjuvant treatment modality may be important for patients whose tumors have strong ILK expression. In the future, small molecule antagonists of ILK may be used to interfere with recurrence in tumor patients.

\section{Conclusion}

Our study demonstrates that ILK expression is a poor prognostic factor in patients with NSCLC. Thus, the utility of the expression of ILK could open up a new window for the molecular marker and the treatment of NSCLC.

\section{Competing interests}

The author(s) declare that they have no competing interests.

\section{References}

I. Giancotti FG, Ruoslahti E: Integrin signaling. Science 1999, 285: 1028-1032.

2. Adachi M, Taki T, Huang C, Higashiyama H, Doi O, Tsuji T, Miyake M: Reduced integrin alpha3 expression as a factor of poor prognosis of patients with adenocarcinoma of the lung. I Clin Oncol 1998, 16:1060-1067.
3. Oshita F, Kameda Y, Ikehara M, Tanaka G, Yamada K, Nomura I, Koda $K$, Shotsu A, Fujita A, Arai A, Ito $H$, Nakayama $H$, Mitsuda $A$ : Increased expression of integrin betal is a poor prognosis in small cell lung cancer. Anticancer Res 2002, 22:1065-1070.

4. Han JY, Kim HS, Lee SH, Park WS, Lee JY, Yoo NJ: Immunohistochemical expression of integrins and extracellular matrix proteins in non-small cell lung cancer: correlation with lymph node metastasis. Lung Cancer 2003, 41:65-70.

5. Adachi M, Taki T, Higashiyama M, Kohno N, Inufusa H, Miyake M: Significance of integrin $\alpha 5$ gene expression as a prognostic factor in node-negative non-small cell lung cancer. Clin Cancer Res 2000, 6:96-I0I.

6. Hannigan GE, Leung-Hagesteijin C, Fitz-Gibbon L, Coppolino MG, Redeva G, Filnus J, Bell JC, Dadhar S: Regulation of cell adhesion and anchorage-dependent growth by a new lintegrin-linked protein kinase. Nature (Lond) 1996, 379:91-96.

7. Radeva G, Petrocelli T, Behrend E, Leung-Hugesteijin C, Filmus J, Singerlard J, Dadhar S: Overexpression of the integrin-linked kinase promotes anchorage-independent cell cycle progression. J Biol Chem 1997, 272: I3937-I3944.

8. Graff JR, Deddens JA, Konicek BW, Colligan MM, Hurst BM, Carter $\mathrm{HW}$ : Integrin-linked kinase expression increases with prostate tumor grade. Clin Cancer Res 200I, 7:1987-1991.

9. Itoh R, Oue N, Zhu X, Yoshida K, Nakayama H, Yokozaki H, Yasui W: Expression of integrin-linked kinase is closely correlated with invasion and metastasis of gastric carcinoma. Virchows Arch 2003, 442: I I8- 123.

10. Marotta A, Tan C, Gray V, Malik S, Gallinger S, Sanghera J, Dupuis B: Dysregulation of integrin-linked kinase (ILK) signaling in colonic polyposis. Oncogene 200I, 20:6250-6257.

II. Sobin LH, Wittekind $\mathrm{CH}$, editors: International Union Against Cancer TNM Classification of Malignant Tumors. 5th edition. New York: John Wiley and Sons, Inc; 1997:9I-97.

12. Persad S, Attwell S, Gray V, Delcommenne M, Trousard A, Sunghera J, Dadhar S: Inhibition of integrin-linked kinase (ILK) suppresses activation of protein kinase B/Akt and induces cell cycle arrest and apoptosis of PTEN-mutant prostate cancer cells. Proc Natl Acad Sci USA 2000, 97:3207-32I 2.

13. Delcommenne M, Tan C, Gray V, Rue L, Woodgett J, Dedhar S: Phosphoinositide-3-OH kinase-dependent regulation of glycogen synthase kinase 3 and protein kinase B/AKT by the integrin-linked kinase. Proc Natl Acad Sci USA 1998, 95:II2II-II2I6.

14. Novak A, Hsu SC, Leung-Hagesteijn C, Radeda G, Pupkoff J, Montesano R, Roskelley C, Grosschedi R, Dadhar S: Cell adhesion and integrin-linked kinase regulate the LEF-I and catenin signaling pathways. Proc Natl Acad Sci USA 1 998, 95:4374-4379.

15. Persad S, Troussard AA, McPhee TR, Mulholland DJ, Dedhar S: Tumor suppressor PTEN inhibits nuclear accumulation of beta-catenin and $T$ cell/lymphoid enhancer factor 1 -mediated transcriptional activation. J Cell Biol 200 I, I 53: I I6I-I I74.

16. Wu C, Keightley SY, Leung-Hagesteijin C, Radeva G, Coppolino M, Goicoechea S, McDonald JA, Dadhar S: Integrin-linked protein kinase regulates fibronectin matrix assembly, E-cadherin expression, and tumorigenicity. J Biol Chem 1998, 273:528-536.

17. Dai DL, Makretsov N, Campos El, Huang C, Zhou Y, Huntsman D, Martinka M, Li G: Increased expression of integrin-linked kinase is correlated with melanoma progression and poor patient survival. Clin Cancer Res 2003, 9:4409-44I4.

18. Troussard AA, Costello P, Yaganathan TN, Kumagai S, Roskelly CD, Dedhar S: The integrin-linked kinase (ILK) induces an invasive 
phenotype via AP-I transcription factor-dependent upregulation of matrix metalloproteinase 9 (MMP-9). Oncogene 2000, 19:5444-5452.

19. Ahmed N, Riley C, Oliva K, Stutt E, Rice GE, Quinn MA: Integrinlinked kinase expression increases with ovarian tumor grade and is sustained by peritoneal tumour fluid. J Pathol 2003, 20I:229-237.

20. Rosell R, Li S, Skacel Z, Gonez-Codina J, Camps C, Maestre J, Radille J, Canto A, Mate JL, Li S, Roig J, Olabansal A: A randomized trial comparing preoperative chemotherapy plus surgery with surgery alone in patients with non-small-cell lung cancer. $N$ Eng J Med 1994, 330:153-158.

21. Roth JA, Fossella F, Komaki R, Ryan MB, Putnam JB Jr, Lee JS, Dhingra $H$, De Caro L, Chasen M, McGrabran M: A randomized trial comparing perioperative chemotherapy and surgery with surgery alone in respectable stage IIIA non-small-cell-lung cancer. J Natl Cancer Inst 1994, 86:673-680.

\section{Pre-publication history}

The pre-publication history for this paper can be accessed here:

http://www.biomedcentral.com/1471-2407/5/1/prepub

Publish with Bio Med Central and every scientist can read your work free of charge

"BioMed Central will be the most significant development for disseminating the results of biomedical research in our lifetime. "

Sir Paul Nurse, Cancer Research UK

Your research papers will be:

- available free of charge to the entire biomedical community

- peer reviewed and published immediately upon acceptance

- cited in PubMed and archived on PubMed Central

- yours - you keep the copyright 